ÖZEL HUKUK / PRIVATE LAW

Araştırma Makelesi / Research Article

\title{
Sosyal Medya Adları ve Türk Medeni Kanunu m. 26 Kapsamında Sosyal Medya Adlarının Korunması*
}

\author{
Social Media Names and Protection of Social Media \\ Names under Turkish Civil Code Art. 26
}

\section{Buğra Kaan ÇAKIROĞLU*}

\section{öz}

Sosyal medya mecralarında kullanılan tüm adları, sosyal medya adları olarak ifade etmek gerekir. Bu adların içerisine, "web 2.0" teknolojisi içinde yer alan ve kişileri tanımlayan tüm işaretler girer. Bu kapsamda domain adları, internet alan adları veya herhangi bir sosyal medya uygulamasındaki kullanıcı adı örnek olarak gösterilebilir. Kişiler tarafindan sosyal medyada kullanılan adlar, bireyin sahip olduğu ad gibi, onu diğer sosyal medya kullanıcılarından ayırabilir, diğer kullanıcılarla etkileşime geçmesini sağlayabilir. Bu özelliği ile sosyal medya adlarının da Türk Medeni Kanunu (TMK) madde (m.) 26 kapsamındaki korumadan yararlanabilmesi gerekir. Fakat sosyal medya adları her zaman, kişiyi bireyselleştirme ve tanıtma fonksiyonunu ihtiva etmez. Bu farklılığa sebep olan durum, sosyal medya uygulamalarındaki farklılıktan veya kişinin adını belirlemesindeki farklılıktan meydana gelebilir. Sonuçta sosyal medya adlarının bireyi tanıtma ve diğer bireylerden ayırma işlevi sağlanmadıkça TMK m. 26 ve kişiliği koruyan diğer hükümlerden yararlanmak mümkün olmayacaktır.

Anahtar Kelimeler: Ad, adın korunması, sosyal medya, sosyal medya adları, kullanıcı adları, takma adlar, sosyal medya adlarının korunması.

\section{ABSTRACT}

All names used in social media applications should be expressed as social media names. All signs in "web 2.0" technology and identifying people are included in these names. In this context, domain names, internet domain names, or user name in

* Makale gönderim tarihi: 08.05.2020. Makale kabul tarihi: 13.05.2020. Buğra Kaan Çakıroğlu, "Sosyal Medya Adları ve Türk Medeni Kanunu m. 26 Kapsamında Sosyal Medya Adlarının Korunması", İstanbul Medipol Üniversitesi Hukuk Fakültesi Dergisi, Cilt 7, Sayı 1, 2020, s. 191-214; https://doi.org/10.46547/imuhfd.2020.07.01.01.

* Ar. Gör., İstanbul Medipol Üniversitesi Hukuk Fakültesi Medeni Hukuk Anabilim Dalı. İletişim: İstanbul Medipol Üniversitesi Hukuk Fakültesi - Göztepe Mah. Atatürk Cad. No: 40/16 34815 Beykoz/İstanbul, bkcakiroglu@medipol.edu.tr, () https://orcid.org/oooo-ooo3-33233233 . 
any social media application can be shown as examples. The names used by people on social media, like the name that the individual has, can separate it from other social media users and enable it to interact with other users. With this feature, social media names can also be able to benefit from the protection within the scope of Article (Art.) 26 of the Turkish Civil Code (TCC). But social media names do not always include individualization and identification of the person. The situation that causes this difference may be due to the difference in social media applications or the difference in determining the person's name. As a result, unless the function of identifying the individual and distinguishing other individuals, TCC Art. 26 and other provisions protecting the personality will not apply for social media names.

Keywords: Name, protection of name, social media, social media names, username, nicknames, protection of social media names.

\section{Giriş}

Bilindiği üzere ad, bireyin toplumda tanınmasını sağlayan, onu diğer bireylerden ayırmayı sağlayan bir araçtır. Kişilik haklarının korunmasını düzenleyen 4721 Sayılı Türk Medeni Kanunu (TMK), adın korunmasına ayrı bir önem atfetmiş ve madde (m.) 26 hükmünde adın korunmasını ayrıca düzenlemiştir.

Buna karşın sosyal medyada kullanılan isimler bakımından mevzuatımızda herhangi bir hüküm bulunmamaktadır. Kişiler tarafından sosyal medyada kullanılan kullanıcı adları, bireyin sahip olduğu ad gibi, onu diğer sosyal medya kullanıcılarından ayırabilir, diğer kullanıcılarla etkileşime geçmesini sağlayabilir ve onun tanınmasını sağlayan bir araç olarak kullanılabilir. Zira teknolojinin hızla gelişmesi dolayısıyla sosyal medyanın artık evimizdeki televizyondan elimizdeki cep telefonlarına kadar girmesi, sosyal medya kullanıcı adlarının önemi artırmış ve bunların korunması ihtiyacını ortaya çıkarmıştır. Bu doğrultuda, çalışmamızda bu ihtiyacın TMK m. 26 hükmünde yer alan adın korunması hükümleri ile karşılanıp karşılanamayacağı tartışılacaktır. Ancak konunun daha iyi anlaşılabilmesi ve bütünlüğün sağlanabilmesi açısından ilk olarak TMK kapsamında ad kavramı ve adın korunması hakkında açıklamalarda bulunulacaktır. 


\section{Ad Kavramı}

\section{En önemli kişilik haklarından ${ }^{1}$ olan $\mathrm{ad}^{2}$, bireylerin toplum içinde tanınma-} $\operatorname{sinl}^{3}$ sağlayan, onu diğer kişilerden ayırma işlevine sahiptir ${ }^{4}$. Bu doğrultuda belirtilmesi gereken en önemli husus ise TMK'nın kişiyi ayırt etmeye yarayan tüm işaretleri koruduğudur5. Kişilik hakkı niteliği itibarıyla kişiye sıkı sıkıya bağlı bir hak olduğundan ${ }^{6}$ miras yoluyla geçmez, temlik edilemez ve bu hakkın

1 Ad üzerindeki hakkın hukuki niteliği doktrinde çokça tartışılmış ve bugün hakim olan görüşe göre kişinin adı üzerindeki hakkı bir kişilik hakkıdır. Nitekim ad üzerindeki hak, hukuken korunan kişisel değerlerdendir. Bu durumda TMK m. 26 hükmünde düzenlenmiş olmasaydı dahi ad, TMK m. 24 hükmünce korunabilirdi. Bu yöndeki açıklamalar için bkz. Mustafa Dural, Tufan Öğ̈̈z, Türk Özel Hukuku Kişiler Hukuku, Cilt 2, 14. Bası, Filiz Kitabevi, İstanbul, 2014, s. 165.

2 Adın bir kişilik hakkı olduğuna ilişkin olarak bkz. Doruk Gönen, Tüzel Kişilerde Kişilik Hakkı ve Korunması, On İki Levha Yayıncılı, İstanbul, 2011, s. 61; Serap Helvacı, Türk ve İsviçre Hukuklarında Kişilik Hakkını Koruyucu Davalar, Beta Basım Yayın, İstanbul, 2001, s. 42, 74, (Koruyucu Davalar); Beyza Aka, "Sosyal Medyada Kişilik Hakkı İhlalleri ve Hukuki Korunma Yolları”, İzmir Barosu Dergisi, Cilt 82, Sayı: 2, 2017, s. 244; Mine Kaya, "Telekomünikasyon Alanında Kişilik Haklarının Korunması”, Ankara Barosu Dergisi, Cilt 68, Sayı: 4, 2010, s. 279, 282, (Kişilik Haklarının Korunması); Aytekin Ataay, Şahıslar Hukuku: Giriş, Hakikî Şahıslar, Cilt 1, 2. Bası, İstanbul Üniversitesi Yayınları, İstanbul, 1969, s. 166; Hayrunnisa Özdemir, "Türk ve İsviçre Medenî Hukukunda Ad Üzerindeki Hak ve Korunması”, Ankara Üniversitesi Hukuk Fakültesi Dergisi, Cilt: 57, Sayı: 3, 2008, s. 563; Mustafa Dural, Türk Medeni Hukukunda Gerçek Kişiler, Filiz Kitabevi, İstanbul, 1995, s. 164; Başlarda Fransız hukukunda adın mülkiyet hakkı olduğunun kabul edilmesine karşın, sonraları bu görüş terk edilerek adın bir kişilik hakkı olduğu düşünülmeye başlanmıştır. bkz. Özdemir, s. 583; Eda Sarp, “İsim Hakkı ve İsmin Korunması”, Bursa Barosu Dergisi, Sayı: 93, 2013, s. 65 vd.; Sinan Sami Akkurt, Sosyal Medyada Gerçekleşen İhlaller Karşısında Kişilik Hakkının Korunması, Seçkin Yayıncılık, Ankara, 2019, s. 47. Adın insanlar tarafından kişiye verilmiş bir çağırma ifadesi olduğuna ilişkin olarak bkz. Sarp, s. 59; Kemal Oğuzman, Özer Seliçi, Saibe Oktay-Özdemir, Kişiler Hukuku, 17. Bası, Filiz Kitabevi, İstanbul, 2018, s. 114; Mehmet Ayan, Nurşen Ayan, Kişiler Hukuku, 8. Bası, Seçkin, Ankara, 2016, s. 141; Dural, Öğüz, s. 165.

3 Adın kişiyi tanıtma ve belirtme işlevine sahip olmasına ilişkin olarak ve adın diğer görevlerine ilişkin olarak bkz. Dural, s. 166.

4 Serap Helvacı, Gerçek Kişiler, Legal Yayıncılık, İstanbul, 2017, s. 135, (Gerçek Kişiler); Jale Akipek, Turgut Akıntürk, Derya Ateş, Türk Medeni Hukuku: Başlangıç Hükümleri, Kişiler Hukuku, Cilt 1, 14. Bası, Beta Yayıncllık, İstanbul, 2018, s. 418; Özdemir, s. 563; Dural, s. 164, 166; Ŏ̆uzman, Seliçi, Oktay-Özdemir, s. 114; Sarp, s. 59; Dural, Öğ̈̈z, s. 165.

5 Helvacı, Gerçek Kişiler, s. 135.

6 Yargitay (Yarg.) Hukuk Genel Kurulu (HGK.), 2010/18-135 Esas (E.), 2010/136 Karar (K.), 10.03.2010 Tarih (T.), (28.11.2019), www.kazanci.com: "Özel hukuk açısından ad, kişiyi tanıtan ve onu diğer bireylerden ayırmaya yarayan bir kavramdır. Kendine özgü kişiliği ve özvarlığı olan her birey, başkalarından adıyla ayırt edilir, toplum ve ailesi içinde bununla yer alır. Onun içindir ki her kişinin bir adının olması ve adının nüfus siciline yazılması yasayla zorunlu kılınmıştır. Bu zorunluluk aynı zamanda kişinin yaşamıyla özdeşleşen ve kişiliğinin ayrılmaz bir öğesini oluşturan adını özgürce seçmesi ve onunla tanınması için kendisine tanınmış bir temel kişilik hakkıdır. Türkiye Cumhuriyeti Anayasası ile güvence altına alınmış olan adın, kişilik hakları içerisinde taşıdığı önemi göz önünde bulunduran 4721 sayılı Türk Medeni Yasasında kişiliği korumaya ilişkin hükümlerle yetinilmeyip (m. 23-25), onu ayrıca düzenlemek yoluna gidilmiştir (m. 26-27). Buna göre anılan yasanın 27. maddesi hükmü uyarınca adın değiştirilmesi, ancak haklı nedenlere dayanılarak hakimden istenebilir ise de kişiye sıkı sıkıya bağlı olan ad üzerindeki bu hakkı, kişinin kendisinden başkası kullanamaz.”; Yarg. 18. Hukuk Dairesi (HD.), 2006/8146 E., 2006/7672 K., 12.10.2006 T., (28.11.2019), www.kazanci.com: "Türkiye Cumhuriyeti Anayasası ile güvence alt- 
uzun süre kullanılmaması, adın kaybına yol açmaz .

TMK'da terim olarak, 743 sayılı Türk Kanuni Medenisi’nden (eMK) farklı bir şekilde "isim" kavramı yerine "ad” kavramını kullanmıştır. Nitekim “ad” kavramı daha önce 2525 sayılı Soyadı Kanunu'nda (SK) da kullanılmaktaydı.

Gerçek ve tüzel kişilerin ${ }^{8}$ toplumda diğer bireylerden kendilerini ayırmak, kendilerini tanıtmak için onları bireyselleştirmeye yarayan araçlara ihtiyacı vardır ${ }^{9}$. Gerçek kişiler bu ihtiyacı adları ve soyadları ile karşılamaktadır ${ }^{10}$. İfade etmek gerekir ki gerçek kişilerin, toplumun en temel yapı taşı olan aile içerisinde tanınmasını sağlama fonksiyonu genellikle ad sayesinde olmaktadır. Zira aynı soyadını taşıyan kişiler arasında bireysellik fonksiyonunu ihtiva edecek unsur yine ad olacaktır ${ }^{11}$. Fakat soyadının da bireylerin ayırt edilmesine ve onun tanıtılmasına yarayan bir kelime olduğunu açıkça ifade etmek gerekir. Ancak tüzel kişiler bakımından düşünüldüğünde soyadının bu ihtiyacın karşılanmasında fayda sağlayamayacağını ifade etmek gerekir.

\section{Ad Türleri}

Doktrinde adın türlerine ilişkin çeşitli ayrımlar yapılmaktadır. Buna göre, kullanımı zorunlu veya zorunlu olmayan $\operatorname{adlar}^{12}$, dar ve geniş anlamda $\operatorname{ad}^{13}$ ve benzerleri (vb.) gibi ayrımlar mevcuttur. Biz de adın türleri bakımından dar ve geniş anlamda ad şeklinde bir ayrımı tercih edip; çalışmamızda bu ayrımı esas alarak açıklamalarda bulunacağız.

na alınmış olan adın, kişilik hakları içerisinde taşıdığı önemi gözönünde bulunduran 4721 Sayıl Türk Medeni Yasasında kişiliği korumaya ilişkin hükümlerle yetinilmeyip (m. 23-25), onu ayrıca düzenlemek yoluna gidilmiştir (m. 26-27) . Buna göre anılan Yasanın 27. maddesi hükmü uyarınca adın değiştirilmesi, ancak hakh nedenlere dayanılarak hakimden istenebilir ise de kişiye sıkı sıkıya bağh olan ad üzerindeki bu hakkı, kişinin kendisinden başkası kullanamaz. O halde somut olayda, yaşamı süresince nüfus kütüğünde yazıl (Öncüöncün) soyadını taşıyıp bu soyadla öldüğü anlaşılan kişinin murisin soyadının değiştirilmesi istemiyle davacılar (mirasçıları ana ve oğulları) tarafindan açllan davanin aktif husumet ehliyeti yokluğundan reddi gerekirken, mahkemece işin esasına girilerek istem gibi hüküm kurulmuş olması usul ve yasaya aykırı görülmüştür."

7 Bilge Öztan, Medeni Hukukun Temel Kavramlarl, 36. Bası, Turhan Kitabevi, Ankara, 2012, s. 295; Akkurt, s. 47; Oğuzman, Seliçi, Oktay-Özdemir, s. 114.

8 Ad üzerindeki hakkın gerçek kişiler kadar tüzel kişilere de tanındığına ilişkin olarak bkz. Helvacı, Gerçek Kişiler, s. 136; Sarp, 59; Oğuzman, Seliçi, Oktay-Özdemir, s. 115; Ayan, Ayan, s. 141.

9 Akipek, Akıntürk, Ateş, s. 418; Akkurt, s. 47.

10 Akkurt, s. 47; Akipek, Akıntürk, Ateş, s. 418.

11 Soyadının, aynı aile bireylerini, diğer aile bireylerden ayırmaya yarayan bir ad olduğu yönündeki tanım için bkz. Dural, Öğüz, s. 166

12 Dural, s. 164 vd; Hüseyin Hatemi, Kişiler Hukuku, 7. Bası, On İki Levha, İstanbul, 2018, s. 59; Dural, Öğ̈̈z, s. 165 .

13 Akipek, Akıntürk, Ateş, s. 419 vd. 


\section{A. Dar Anlamda Ad}

Dar anlamda ad olarak tanımlanan ad, hukuk düzenince tanınan kişilerin sahip olduğu gerçek addır ${ }^{14}$. Bu tanımlama kapsamında adın iki unsurdan oluştu$\breve{g u n u}$ belirtmek gerekir. Bunlar kişinin sahip olduğu öz $\operatorname{ad}^{15}$ ve soyadıdır. Kişinin sahip olduğu öz ad ve soyadı ise hem kanunda gerçek kişiler için esas alınan, hem de alınması zorunlu olan adlardır. Gerçekten de SK m. 1 ve 2 hükümlerinde de dar anlamda adı oluşturan öz ad ve soyadının kullanılmasını zorunlu kılmıştır.

Soyadı, bir kişinin baba tarafından bağlı olduğu ailenin ${ }^{16}$ nesilden nesile geçen adıdır ${ }^{17}$. Bu tanım kapsamında değerlendirildiğinde, bir ailenin fertlerini birbirine bağlayan ${ }^{18}$, onun soybağının nereden geldiğini tanımlayan bir kelimedir ${ }^{19}$.

Kişinin dar anlamda adı, kişiyi toplum içerisinde bireyselleştirir. Ancak yukarıda da bahsedildiği üzere soyadı bu fonksiyonu tek başına ihtiva edemeyecektir $^{20}$. Çünkü soyadı yalnızca kişiyi, aynı ailelerden olmayanlar için ayırmaya yarayabilecek bir kelimedir. Bu sebeple herkesin SK'ya göre, soyadı yanında ad alması zorunlu tutulmuştur.

\section{B. Geniş Anlamda Ad}

Geniş anlamda ad ise, dar anlamda addan farklı olarak kişileri belirtmeye yarayan ve hukuken korunan tanıtım kelimelerinin tümünü ifade eder ${ }^{21}$. Geniş anlamda ad kavramı kişinin toplum ve diğer bireylerden kendini ayırdığı, kendini tanıtmaya yarayan araçlardandır. Dolayısıyla kişinin toplumdan kendisini ayırabildiği ve kendisini tanıtmaya yarayan her ad bu kapsam içerisine girebilir ${ }^{22}$. Bu sebeple geniş anlamda ad kapsamına girebilecek adları sayı ile sınırlamak mümkün değildir. Nitekim kişilik hakkı olarak ifade ettiğimiz adı yalnızca dar anlamda ad olarak değerlendirmek mümkün değildir ${ }^{23}$.

14 Akipek, Akıntürk, Ateş, s. 419.

15 Bilimsel eserlerde bu kelime yer yer ön ad şeklinde de kullanılmaktadır. bkz. Akkurt, s. 47.

16 Kadının evlenmesi durumunda soyadının değişmesi hali bu durumun bir istisnasını teşkil etmektedir.

17 Akipek, Akıntürk, Ateş, s. 419; Öztan, s. 295; Dural, s. 165; Oğuzman, Seliçi, Oktay-Özdemir, s. 115; Ayan, Ayan, s. 141.

18 Öztan, s. 295.

19 Soyadının özellikle evli kadınlar ve çocuklar bakımından bir statü belirttiğine ilişkin olarak bkz. Özdemir, s. 565 .

20 Ad bir kişinin kendisini dış dünyaya tanıtmasında kullandığı bir araçtır. Bu niteliği ile ad, bireyin kendi soyadını taşıyan kişilerden ayırt edilmesini sağlayan, manevi bütünlüğe ilişkin bir kişilik değeridir. Bu yöndeki görüşler için bkz. Akkurt, s. 47 vd.

21 Akipek, Akıntürk, Ateş, s. 420.

22 Internet alanında kullanılan ve diğer sunuculardan ayrılan adreslerde adın kapsamı dahildedirler. Bu görüş için bkz. Özdemir, s. 564; Sarp, s. 59.

23 Aka, s. 245 . 


\section{Müstear Ad (Mahlas)}

Bir kişinin, gerçek adını kullanmak yerine çeşitli sebeplerle kendisine takmış olduğu addır ${ }^{24}$. Bu ad kişi tarafından serbestçe seçilebilir ${ }^{25}$. Nitekim sanatçllar, yazarlar vb. gibi sanat eserleri icra eden kişiler meydana getirdikleri eserlerin altına öz adlarından başka adlarla imza atabilirler ${ }^{26}$. Bu halde kişiler öz adları yerine müstear adlarını kullanır. Ancak müstear adda, öz ad ve soyadı gibi kişiyi tanımlar, bireyselleştirir ve diğer kişilerden ayırma fonksiyonunu tesis eder ${ }^{27}$. Belirtmek gerekir ki mahlas, yani müstear ad, TMK'da düzenlenmemiştir $^{28}$. Buna karşın 5846 Sayılı Fikir ve Sanat Eserleri Kanunu m. 11, müstear ad bakımından da düzenlemeye yer vermiştir. Buna göre, "yayımlanmış eser nüshalarnda veya bir güzel sanat eserinin aslında, o eserin sahibi olarak adını veya bunun yerine tanımmıs müstear adın kullanan kimse, aksi sabit oluncaya kadar o eserin sahibi sayılır."

$\mathrm{Bu}$ tür adları genellikle sanatçılar, yazarlar ve çeşitli sanat faaliyetlerinde gerçek adlarını gizlemek için kullanırlar ${ }^{29}$. Nitekim bazı kişiler, meslekleri, toplumda bulundukları konumları sebebiyle isimlerinin yaptıkları çalışmalarda veya işlerde anılmasından çekince duyabilir. Dolayısıyla bu kişiler kendilerine ait olan ve toplumda tanınmalarını sağlayacak isimlerini değil de kendilerine takmış oldukları mahlas ile sonucunun nereye varacağına dair çekincelerinin ortadan kalkması sayesinde yaptıkları çalışmaları toplumun önüne serebilirler.

Gerçekten de müstear ad kullanımı çok eski zamanlardan beri yaygın konumdadır. Buna örnek olarak Peyami Safa'nın polisiye romanları için kullandığı Server Bedi mahlası, Kanuni Sultan Süleyman'ın kullandığı Muhibbi mahlası gösterilebilir. Bazen de kişilerin mahlas kullanmalarının sebebi gerçek kişiliklerini tanımlayan adlarını gizlemek değil de kullandıkları mahlas sayesinde toplumun hafızasında kalıcı olabilmektir.

Öztan, s. 297; Dural, s. 165; Akipek, Akıntürk, Ateş, s. 420; Akkurt, s. 50; Ayan, Ayan, s. 141.

25 Bazı meslekler bakımından, bu kişilerin meslekleri ile ilgili müstear adın alınamaması gerektiği ve buna ilişkin bir sınırlama getirilmesi gerektiğine ilişkin görüşler için bkz. Ergun Özsunay, Gerçek Kişilerin Hukuki Durumu, 4. Bası, İstanbul Üniversitesi, İstanbul, 1979, s. 188. Yine tanınmış bir kişinin isminin müstear ad olarak kullanılamayacağına ilişkin olarak bkz. Sarp, s. 65 .

26 Ataay, s. 162; Özdemir, s. 567.

27 Adın ayırma fonksiyonuna iliş̧in detaylı bilgi için bkz. Özdemir, s. 564; bkz. s. 2.

28 Müstear adın TMK'da düzenlenmemiş olmasına karşın; kişi genellikle bu ad ile tanınıyorsa TMK m. 26 kapsamında korumadan yararlanabilecektir. bkz. Dural, Öğüz, s. 166

29 Oğuzman, Seliçi, Oktay-Özdemir, s. 116; Dural, Öğüz, s. 166; Ataay, s. 162. 


\section{Lakap}

Lakap, bir kişiye başkaları tarafından bir ayırt edici özelliği kullanılarak takılan addır ${ }^{30}$. Bu ad başkaları tarafından kişinin belirgin özelliklerine göre belirli bir çevrede takılır ve kişi bu lakabı sayesinde anılır, ayırt edilir ${ }^{31}$. Dolayısıyla kişinin toplum içerisinde bireyselleşme fonksiyonu bu ad türünde de sağlanır. Ancak lakap kişi tarafından yalnızca kendisine o ismi takan kişiler çevrelerce kullanılacağından bu fonksiyon bazı çevrelerle sınırlı olarak sağlanır. Bir başka kimseler tarafından kişiye takılan ad yani lakap bu özelliği ile de müstear addan farklıdır.

\section{Sosyal Medya Adları (Nicknames)}

Gelişen teknoloji ve iletişimin hızlanması sebebiyle günümüz toplumunun sosyalleşme ihtiyacının giderildiği en büyük araç sosyal medya olmuştur. Buna rağmen sosyal medyaya ilişkin net bir tanım yapılamamakta, çeşitli perspektiflerden farklı tanımlarla sosyal medya kavramı açıklanmaya çalışılmaktadır ${ }^{32}$. Kaplan/Haenlein sosyal medyayı web 2.o teknolojisinin ideolojik ve teknolojik yapıları üzerine inşa edilmiş ve kullanıcı tarafından üretim ve değişimlere izin veren internet tabanlı uygulamalar grubu olarak tanımlamıştır ${ }^{33}$. Yine Boyd/ Ellison sosyal ağ sitelerini, sınırlı bir sistem içerisinde kişilere, herkese açık veya yarı açık profil oluşturma imkânı veren ve sistemdekilerin başkalarıyla bağlantılarını görüntüleyip dolaşma izni veren web tabanlı hizmetler olarak nitelendirmektedir ${ }^{34}$. Buna ek olarak Brunty/Helenek'e göre sosyal medya, ağın bir parçası olan kullanıcıların diğer kullanıcılar veya site oluşturucuları ile iletişimini teşvik eder ve kullanıcıların içerik paylaşması ve/veya benzer ilgi alanlarıyla bağlantı kurması için bir ortam yaratır ${ }^{35}$. Biz de sosyal medyaya ilişkin hukuk perspektifi ile bir tanım yapacak olursak sosyal medya, kişilerin web 2.0 teknolojisi ile gerek içerik paylaşabildiği gerekse başka vasıtalarla iletişimini sağlayan ve bu iletişim sayesinde kişilerin hukuki işlemlerini de yürütebileceği ve ayrıca hukuka aykırı fillerinden sorumlu olabileceği bir uygulamadır.

30 Dural, s. 165; Akkurt, s. 51; Öztan, s. 297; Akipek, Akıntürk, Ateş, s. 420; Sarp, s. 65.

31 Dural, Öğüz, s. 167; Oğuzman, Seliçi, Oktay-Özdemir, s. 116. Lakabın ayırt etme fonksiyonuna ve kişinin belli bir aileye mensup olduğunu gösterdiğine ilişkin Federal Mahkemesi kararı için bkz. Özdemir, s. 564; Dural, Öğüz, s. 167.

32 Mine Kaya, "Sosyal Medya ve Sosyal Medyada Üçüncü Kişilerin Kişilik Haklarının İhlali”, Türkiye Barolar Birliği Dergisi, Sayı: 119, 2015, s. 278.

33 Andreas M. Kaplan, Michael Haenlein, "Users of The World, Unite! The Challenges and Opportunities of Social Media", Business Horizons, Sayl: 53, 2010, s. 61.

34 Danah M. Boyd, Nicole B. Ellison, "Social Network Sites: Definition, History and Scholarship", Journal of Computer-Mediated Communication, Sayı: 13, 2008, s. 211.

35 Joshua Brunty, Katherine Helenek, Social Media Investigations for Law Enforcement, Anderson Publishing, Massachusetts, 2013, s. 2 vd. 
Belirtmek gerekir ki sosyal medya mecralarında ${ }^{36}$ birbirleriyle iletişim kuran kişilerin sayısı günden güne artmakta ve bu iletişimden geri kalmak istemeyen gerçek ve tüzel kişiler Twitter, Instagram, Facebook vb. gibi sosyal mecralarda daha aktif olmaya başlamaktadır ${ }^{37}$. Nitekim kişilerin sosyal medya mecralarında faaliyet gösterebilmeleri için -anonim olarak kullanabildikleri sosyal medya mecralar hariç olmak üzere- genellikle bu mecralara üye olmaları, dolayısıyla kendilerine bir kullanıcı adı almaları gerekmektedir.

Kişilerin fiziki ortamlarda olduğu gibi, sosyal mecralarda da kendilerini diğer üyelerden veya kullanıcılardan ayırdıkları en önemli bireyselleştirme ve tanıtma aracı addır ${ }^{38}$. Bu doğrultuda sosyal medya kullanıcılarının çeşitli sosyal mecralarda edindiği adların TMK m. 26 kapsamında korunabilmesi açısından kişilerin bu mecralar üzerinde elde ettiği isimlerin sınıflandırılması gerekmektedir. Nitekim bu sinıflandirma sonucunda, hangi sosyal medya isimlerinin TMK kapsamında korunabileceği ortaya çıkacaktır.

Son olarak belirtmek gerekir ki, internet sunucu adresleri, alan adlar ${ }^{39} \mathrm{da}$ kanaatimizce adın korunması kapsamında yer alacaktır ${ }^{40}$. Zira kişileri birbirinden ayırmayı sağlayan her kelime adın korunması kapsamındadır ${ }^{41}$. Bu durumda aşağıda açıklanacak koruma hükümleri sunucu adresleri, internet alan adları bakımından da geçerli olacaktır ${ }^{42}$. Ancak konumuz salt sosyal medya adları ile ilişkili olduğundan, açıklamalarımızı da bu çerçeve ile sınırlı tutuyoruz.

36 Çalışmamızda "sosyal medya mecraları" ifadesi ile, yine çalışmada tanımını yaptı̆̆ımız "sosyal medya" uygulamalarının tümü kastedilmektedir.

37 Sosyal medyanın farklı kullanımı ve yararının, bu iletişim biçiminin bu kadar popüler olmasının ana nedeni olduğu ve çoğu sosyal medya sitesinin ücretsiz ve katılmak isteyen herkese açı olması sebebi ile sosyal medyanın artık sadece arkadaşlarla iletişimde kalmak için değil; tüketiciler, işletmeler ve kuruluşlar da dahil olmak üzere herkesin aktif olarak faaliyet gösterdiği bir ortam olduğuna ilişkin açıklamalar için bkz. Burnty, Helenek, s. 17 vd.

38 Zira Brunty, Helenek sosyal medya kimliğinin, kişinin diğer üyeler tarafından nasıl tanındığını ifade ettiğini ve bu kimliğin içerisinde ad da dahil olmak üzere avatar, profil, fotoğraf vb. unsurların yer aldığından bahsetmiştir. bkz. Burnty, Helenek, s. 9 vd.

39 İnternet alan adının, kişiye ait gerçek ada dayanması durumunda bu korumanın ne olacağına ilişkin RG. 07.11.2010/27752 sayılı İnternet Alan Adları Yönetmeliği ve RG. 21.08.2013/28742 sayılı İnternet Alan Adları Tebliği bu konuda ayrıntılı düzenlemelere yer vermemektedir.

40 Özdemir, s. 564; Oğuzman, Seliçi, Oktay-Özdemir, s. 117.

41 Özdemir, s. 569.

42 Alan adlarının, kişiye ait ada dayanması durumunda hangi hükümler kapsamında korunacağını tartışmak gerekir. Bu durumda TMK m. 26 hükmünün öncelikle uygulanacağını ifade etmekle beraber, adı hukuka aykırı şekilde kullanılan taraf TMK m. 25 hükümlerine de başvurabilecektir. Alan adının kişiye ait bir ad olmadığını belirtmekle beraber, bu adın zamanla bilinirlik, ayırt edilme unsurlarını taşıması halinde TMK m. 26 hükümleri çerçevesinde korunacağına yönelik görüşler için bkz. Oğuzman, Seliçi, Oktay-Özdemir, s. 117. 


\section{a. Anonim Kullanıcı Adları}

Sosyal medya mecralarından bazıları kişilerin, kendi mecralarında faaliyet gösterebilmesi yani diğer kişiler ile iletişime geçebilmesi, yazılar yazabilmesi, fotoğraf ve video paylaşabilmesi veya oyun oynayabilmesi vb. bakımından, kişilerin kendi sistemlerine kayıt olmasını ve bununla beraber diğer kişiler tarafından tanınmasını ve ayırt edilmesini sağlayan kullanıcı adları almalarını zorunlu tutmaktadır. Hatta alacakları kullanıcı adlarının diğer kullanıcı adlarından farklı olması genellikle her sosyal medya mecrası için zorunlu bir unsurdur. Buna karşın bazı sosyal medya mecraları kişilerin kendi sistemlerinde faaliyette bulunabilmesi için, misafir kullanıcılara izin vermekte veya onların sisteme üye olmasını ve dolayısıyla kullanıcı adı almalarını gerektirmeksizin iş ve işlem yapabilmelerine, diğer üyeler ile iletişime geçebilmelerine vs. izin vermektedir.

Belirtmek gerekir ki anonim olarak sosyal medya mecralarında hareket eden kullanıcıların genellikle o mecralardaki misafir kullanıcı isimleri sisteme her girişlerinde değiştiğinden, bu kişiler bakımından TMK kapsamında gerçek bir ad kullandıklarından bahsedilemeyecektir. Çünkü anonim kişilerin sosyal medya mecralarında kullandıkları adlar, adın bireyselleşme ve diğer kullanıcılardan ayırt edilme fonksiyonunu sağlamamaktadır. Buna karşın sosyal medya mecralarında anonim olarak kullanılmakla beraber, kullanılan sosyal mecraya her girişte kişinin aynı anonim ada ulaşması bireyselleşme ve kendini diğer kullanıcılardan ayırma fonksiyonu taşıyacağından aşağıda bu konu ayrıca incelenecektir.

\section{b. Nüfusa veya Sicile Kayıtlı Olan Adları İçeren Kullanıcı Adları}

Kendi sistemlerinde faaliyette bulunabilmeleri için üye olma şartı arayan ve dolayısıyla kişilerin kullanıcı adı almasının zorunlu olduğu sosyal mecralarda, kişiler nüfusa veya sicile kayıtlı isimlerini kullanabilecektir. Bu sayede kişiler, sosyal medya mecralarından edindikleri kullanıcı adlarıyla, bu mecralarda kendilerini bireyselleştirme, tanıtma ve diğer kullanıcılardan ayırt edilebilme imkânını elde etmektedirler. Hatta bazı sosyal medya mecralarında kişisel hesaplarının çeşitli yollarla doğrulanması sağlanarak, kişilere o sosyal medya bakımından gerçek hesap (resmi, orijinal hesap) statüsü sağlanmaktadır.

Belirtmek gerekir ki sosyal medya mecralarında faaliyet gösteren kişiler yalnızca gerçek kişiler değildir. Gerçekten de özellikle reklam ve tanıtım amacıyla birçok tüzel kişi sosyal medya mecralarında faaliyet göstermektedir. Bu açıdan değerlendirildiğinde, gerçek ve tüzel kişilerin adları üzerindeki haklarına saldırılar mevcut olabilir. Sosyal medya isimlerinin korunmasını aşağıda in- 
celeyeceğimizden ${ }^{43}$, bu başlık altında sosyal medya mecralarında nüfusa veya sicile kayıtlı isimlerini kullanan kullanıcıların TMK kapsamındaki haklardan yararlanabileceğini belirtmekle yetiniyoruz.

\section{c. Nüfusa veya Sicile Kayıtlı Olmayan Adları İçeren Kullanıcı Adları}

Sosyal medya mecralarında kişilerin genellikle nüfusa kayıtlı resmi isimlerini kullanmaması yaygın bir durumdur. Bu durumun tüzel kişiler bakımından geçerli olduğu söylenemez. Çünkü sosyal medya mecralarında faaliyet gösteren tüzel kişiler genellikle bu vasıtalar ile reklam yapmaya ve dolayısıyla tanınabilirliklerini artırmaya çalışmaktadırlar. Bu halde tüzel kişiler bakımından böyle bir durumun mantık kuralları dahilinde mümkün olmadığını öngörmekteyiz. Dolayısıyla sosyal medya mecralarında kullanılan bu adların incelenmesini, gerçek kişilerle sınırlı olarak yapacağız.

Yukarıda da değinildiği üzere sosyal medya mecralarında nüfusa kayıtlı olmayan adlarını kullanan birçok kullanıcı mevcuttur. Bu adların kişileri bireyselleştirme ve onları tanıtma fonksiyonuna sahip olduğunun kabul edilmesi gerekmektedir ${ }^{44}$. Hatta son yıllarda sosyal medyanın hızla gelişmesi sebebiyle kişilerin kendilerini tanıtma ve onların toplum içerisinde bireyselleştirilmesi fonksiyonunu en çok sağladığı aracın sosyal medya olduğu kabul edilebilir. Örneğin, sosyal medyada tanınmış bir kişinin günlük hayatta da bu isimle anıldı$\breve{g}$, haklarında çıkan haberlerde bu isimle anıldıkları herkes tarafından bilinen bir gerçektir.

Son olarak, nüfusa kayıtlı olmayan isimlerin sosyal medya mecralarında kullanılmasının bir diğer hali de anonim adlarda ortaya çıkar. Gerçekten de yukarıda bahsettiğimiz üzere, bazı sosyal medya mecralarında faaliyet gösterebilmek için bu mecralara üye olunması, bir başka ifadeyle kullanıcı adı edinilmesi gerekmemektedir. Ancak bazı durumlarda kişiler sosyal medya mecralarında sürekli olarak aynı anonim ada sahip olurlar. Örneğin bazı sosyal medya mecralarında IP adresi veya farklı bir sistemsel özelliği ile kişilere ayrı anonim isimler verilebilir. Bu durumda, bu sosyal medya mecralarına katılan kullanıcılar hep aynı kullanıcı adını edinebilirler. Böylece kişileri tanıtma ve onları diğer üyelerden ayırma fonksiyonu bu anonim adlar vasıtası ile sağlanabilir 45 .

43 bkz. Bölüm 3 vd.

44 Sosyal medya hesaplarında kullanılan nickname, avatar, rumuz vb. gibi ifadelerin müstear ad kapsamında değerlendirileceği ve bu sebeple TMK $\mathrm{m}$. 26 hükümleri kapsamında korunacağına ilişkin olarak bkz. Akkurt, s. 50.

45 Akkurt eserinde sosyal medya adları bakımından bir ayrıma gitmemiş, tüm sosyal medya adları$\mathrm{nı}$, sosyal medya müstear adı olarak nitelendirmiştir. Nitekim sosyal medya müstear adlarının ve elektronik posta hitaplarının kişilik hakkı kapsamında değerlendirilebileceğinden bahsetmiştir. Bu görüsslere katılmakla beraber, sosyal medya müstear adı olarak tanımlayabileceğimiz adlar bu 


\section{Adın Korunması}

\section{A. Korumanın Kapsamı}

Ad, kişinin sahip olduğu en önemli kişilik haklarındandır. Nitekim bir kişinin, kendisini tanımlamaya, toplum içinde kendisini ayırt etmeye yarayan en önemli araç addır. Kişilik haklarından olması nedeniyle ad, TMK'da yer alan kişiliğin korunmasına ilişkin hükümler çerçevesinde korunur ${ }^{46}$. Bu kapsamda TMK m. 26, kişilik haklarından “ad”a özel bir önem atfetmiş ve adın korunmasına ilişkin hükümleri, kişilik haklarının korunmasına ilişkin hükümlerden ayırmıştır. Bununla beraber doktrinde TMK m. 26 hükmünün, m. 25 hükmüne ilişkin bir özel düzenleme olduğu ifade edilmektedir ${ }^{47}$.

Adın korunmasına ilişkin TMK m. 26 hükmünün, sosyal medya isimlerini kapsayıp kapsamadığını tespit etmek için bu hükmün kapsamını tespit etmek gerekir. Belirtmek gerekir ki, doktrinde TMK m. 26 hükmünün tüm adlar bakımından, hatta elektronik posta adresleri bakımından da uygulanacağı ifade edilmektedir ${ }^{48}$. Dolayısıyla bu madde kapsamında yalnızca kişinin dar anlamdaki adı olan öz ad ve soyadı değil; geniş anlamda ad kapsamında olan müstear $\mathrm{ad}^{49}$, lakabı ve sosyal medya adları da korunur ${ }^{50}$. Ancak yine doktrinde mahlas

çalışmadaki "Nüfusa ve Sicile Kayıth Olmayan Sosyal Medya Adları" başlı̆̆ına karşıllk gelmektedir. Zira bu başlı̆̆a karşılık gelen sosyal medya müstear isimleri tanımına ilişkin olarak Akkurt’un eserinde, bu adların TMK m. 26 kapsamında koruma altına alınacağı dolaylı olarak ifade edilmiştir. Nüfusa ve sicile kayıtlı olan sosyal medya adlarının korunması bakımından ise bu adlar zaten TMK m. 26 kapsamına girdiğinden ayrıca böyle bir tasnifte bulunulmamıştır. Fakat TMK m. 26 hükmü kapsamının tam olarak saptanabilmesi bakımından anonim adların da bu değerlendirmeye tabi edilmesi gerekir. Bu sebeple biz de çalışmamızda böyle bir tasnifte bulunmayı daha uygun bulduk. Akkurt'un sosyal medya müstear adları ifadesi için bkz. Akkurt, s. 50 vd.

46 Sarp, s. 59 vd.; Korumanın kapsamına yalnızca öz ad ve soyadı değil; müstear ad, kısaltılmış adlar, temsili adlar da girer. bkz. Helvacı, Koruyucu Davalar, s. 75; Akipek, Akıntürk, Ateş, s. 433; Özdemir, s. 567; Ayrıca TMK m. 26 hükmü olmasaydı dahi, adın TMK m. 24, 25 ve TBK m. 49 kapsamında korunabileceği yönünde bkz. Dural, Öğüz, s. 165, 175.

47 Akipek, Akıntürk, Ateş, s. 433; Özdemir, s. 583 vd.; TMK m. 26 hükmünün, m. 24 hükmüne ilişkin prensibin ad bakımından uygulanmasına ilişkin olduğu yönündeki görüşler için bkz. Helvacı, Gerçek Kişiler, s. 137; Oğuzman, Seliçi, Oktay-Özdemir, s. 114, 136. Yarg. HGK., 2010/18-135 E., 2010/136 K., 10.03.2010 T., (28.11.2019), www.kazanci.com: "Türkiye Cumhuriyeti Anayasası ile güvence altına alınmış olan adın, kişilik hakları içerisinde taşıdığ önemi göz önünde bulunduran 4721 sayıl Türk Medeni Yasasında kişiliği korumaya ilişkin hükümlerle yetinilmeyip (m. 23-25), onu ayrıca düzenlemek yoluna gidilmiştir."

48 Helvacı, Gerçek Kişiler, s. 136; Gönen, s. 64; Akipek, Akıntürk, Ateş, s. 433; Akkurt, s. 50; Aka, s. 245.

49 Oğuzman, Seliçi, Oktay-Özdemir, s. 116; Dural, Öğüz, s. 175. Takma adlar kişilerin öz adları gibi adın korunması kapsamına dahildir. Buna ilişkin olarak İsviçre Federal Mahkemesi tarafından verilmiş bir kararda, "Annie Chancel" adlı ünlü şarkıcının takma adının "Sheila" parfüm markası olarak kullanılmasını mahkeme adın korunması kapsamında değerlendirmiş ve kişinin takma adının marka olarak kullanılamayacağına karar vermiştir. Bu yöndeki görüşler için ve karara ilişkin bilgiler için bkz. Özdemir, s. 582.

50 Akkurt, s. 50 vd.; Özdemir, s. 567; Ataay, s. 162; Sosyal medya adlarının müstear ad gibi koru- 
ve lakapların ${ }^{51}$ korunabilmesi için kişinin bu adlar ile tanınmış olması ve dolayısıyla kişinin bu hakkının korunmasını sağlayacak menfaatlerinin bulunması gerekir ${ }^{52}$.

$\mathrm{Bu}$ açıdan değerlendirildiğinde, sosyal medya adlarının da TMK m. 26 hükmü kapsamında korunacağı söylenebilir53 . Ayrıca, TMK m. 26 hükmünün yanında sosyal medya adlarının aynı zamanda kişilik hakkı teşkil etmesi sebebiyle, hukuka aykırılık halinde 6098 sayılı Türk Borçlar Kanunu (TBK) m. 58 hükmü kapsamında tazminat talebine de konu edilebileceğini ifade etmek gerekir. Bununla beraber bir kişilik hakkı olarak ad, TMK m. 24 kapsamındaki korumadan da faydalanır.

Gerçekten de yukarıda belirtildiği üzere sosyal medya adları da kişiyi tanıtma ve onları diğer kullanıcılardan ayırmaya yarayan bir araçtır. Bu haliyle sosyal medya adları da mahlas ve lakapta olduğu gibi kişiye korumaya değer bir menfaat sağladığı hallerde TMK m. 26'da düzenlenen korumadan yararlanabilir. Çünkü sosyal medya isimleri kişinin kanundan kaynaklanan ve edinilmesi zorunlu olan isimlerinden değildir ${ }^{54}$. Bu nedenle lakap ve müstear adda olduğu gibi sosyal medya isimleri bakımından da bu adın ancak kişiyi diğer kişilerden ayırt etme ve tanıtma fonksiyonunu sağlaması durumunda korunmasında haklı bir menfaat oluşacak, ancak bu durumda korunacaklardır.

Sosyal medya mecralarında kullanılan isimlerin her biri bakımından bu korumanın gerçekleştiğini söylemek güçtür. Çünkü sosyal medya adlarından bazıları anonim olarak kullanılmakta ve bu anonimlik, adın, bireyi tanıtma ve bu adı kullanan kişileri diğer kullanıcılardan ayırma fonksiyonunu ihtiva etmemektedir. Dolayısıyla bu işlevlere sahip olmayan adın korunmaya değer bir menfaati olduğundan bahsedilemeyecektir.

Buna karşın, nüfusa ve sicile kayıtlı olan isimlerini sosyal medya mecralarında kullanan kişilerin, bu adlar bakımından korunmaya değer bir menfa-

nabileceğine ilişkin olarak bkz. Sarp, s. 69; Özdemir, s. 585; Dural, Öğüz, s. 175.

51 Lakapların ad olarak kabul edilmediği hallerde dahi kişilik hakları çerçevesinde korunacağı yönündeki görüşler için bkz. Oğuzman, Seliçi, Oktay-Özdemir, s. 116; Özsunay, s. 188; Ataay, s. 164. Lakapların TMK m. 26 hükmünce korunabilmesi için hukuka, genel ahlaka ve adaba uygun olması, sahibinin menfaatine aykırı olmaması ve onunla özdeşleşmiş olması gerektiğine ilişkin görüş için bkz. Sarp, s. 65; Akkurt, s. 51; Ayan, Ayan, s. 141.

Gönen, s. 64; Akipek, Akıntürk, Ateș, s. 433; Aka, s. 245; Bu adların Medeni Kanun kapsamında korunabilmesi için, kişilerin bu adla tanınmış olması gerektiği yönündeki görüşler için bkz. Dural, s. 165; Akkurt, s. 50; Ataay, s. 162; Özdemir, s. 584; Ayan, Ayan, s. 141; Dural, Öğüz, s. 166,175 .

53 Aka, s. 245.

54 Kanunda öz ad ve soyadının edinilmesi zorunlu tutulmuştur. Nitekim 2525 Saylı SK m. 1 hükmü şu şekildedir: "Her Türk öz adından başka soy adını da taşımağa mecburdur." 
atlerinin olup olmadığının tartışma konusu edilmemesi gerekir. Nitekim bu kişilerin sosyal medya mecralarında kullandığı isimler, halihazırda kişilik haklarının içerisinde yer alır. Zira bu kişiler sosyal medya mecralarında bu adları kullanmasalar dahi bu hakka sahiptirler ${ }^{55}$. Bu takdirde, kişi adını sosyal medyada kullanmasa dahi adı aleyhine gerçekleşecek ihlallere karşı, adın korunması için TMK m. 26 hükmüne başvurabilir.

Bununla beraber, nüfusa kayıtlı olmayan adlarını sosyal medya mecralarında kullanan kullanıcılar bakımından, bu adların TMK m. 26 kapsamında korunması için kişinin korunmaya değer bir menfaatinin bulunması gerekir ${ }^{56}$. Gerçekten de nüfusa kayıtlı olmayan isimlerini sosyal medyada kullanan kullanıcıların bu adıyla tanınmış olması, diğer üyelerden bu adla ayrılıyor olması gerekir. Ancak kişilerin sosyal medya adları açısından korunmaya değer menfaatlerinden bahsetmek her zaman mümkün olmayacaktır. Özellikle mahlas ve lakaplar için aranan tanınma şartının sosyal medya adları bakımından da gerçekleşmesi gerekir ki, bu işlevin sağlanamadığı adlar bakımından TMK m. 26 hükmünün uygulama alanı bulacağından bahsetmek doğru olmaz.

Üyelik şartı aramayan ve dolayısıyla kullanıcıların bir kullanıcı adı edinmesini zorunlu tutmayan sosyal medya mecralarında anonim isim edinen kullanıcıların TMK m. 26 hükmü kapsamında kalan korumadan yararlanamayacağını belirtmiştik. Fakat bazı sosyal medya mecralarında kişilerin sürekli olarak aynı anonim adını edinmesi mümkün olabilir. Bu halde ise kişilerin tanınması ve diğer kullanıcılardan ayırt edilebilmesi, kullandığı ad ile mümkün olacaktır. İşte adın bu işlevlerinin sağlandığı hallerde anonim adlar bakımından da adın korunmaya değer bir menfaatinin olduğundan bahsedilecektir.

TMK m. 26 hükmü kapsamındaki korumadan gerçek kişiler yararlanabileceği gibi tüzel kişiler de yararlanabilir ${ }^{57}$. Ancak TTK m. 51 ve m. 52 hükümle-

55 İnternet ortamında kullanılan gerçek adın, adın korunması kapsamında değerlendirileceğine ilişkin olarak bkz. Oğuzman, Seliçi, Oktay-Özdemir, s. 117.

56 İnternet ortamında gerçek adlarını kullanmayan kişilerin, adın korunması hükümlerinden yararlanamayacağı; bu adlar bakımından koruma hükümlerinin yalnızca kişilik hakkı kapsamında olacağına ilişkin görüşler için bkz. Helvacı, Koruyucu Davalar, s. 75; Oğuzman, Seliçi, Oktay-Özdemir, s. 117. Belirtmek gerekir ki, sosyal medyada gerçek ad kullanmayan kullanıcıların adın korunması hükümlerinden yararlandığını söylemek kanaatimizce daha doğru olacaktır. Çünkü müstear ad ve lakapların gerçek ad olmamasına rağmen adın korunması hükümlerinden yararlanacağı konusunda doktrinde görüş birliği mevcuttur. Bu halde sosyal medyada kişiyi tanıtıı ve ayırt edici özellikleri haiz adların, müstear ad ve lakapta olduğu gibi koruma kapsamında yer alması gerekir. Kaldı ki günümüzde sosyal medya da kişiler genellikle nüfusa kayıtlı gerçek adlarını kullanmamaktadır. Bu bakımdan da nüfusa kayıtlı olmayan sosyal medya adlarının koruma kapsamı dışına itilmesi, bu hükmün günümüzde uygulama alanını oldukça daraltacaktır.

57 Kaya, Kişilik Haklarının Korunması, s. 282; Helvacı, Gerçek Kişiler, s. 136; Akipek, Akıntürk, Ateş, s. 433 vd. 
rinde ticaret unvanları, markalar, işaretler ve işletme adlarının korunmasına ilişkin olarak özel hükümlerin olduğunu ifade etmek gerekir.

\section{B. Adın Dava Yoluyla Korunmasi}

Adın korunmasına ilişkin olarak TMK m. 26 hükmü hak sahibine çeşitli davaları açabilme hakkı tanımıştır. Buna göre adının kullanılması çekişmeli olan kişi, TMK m. 26/1 gereği bu hakkının tespiti için dava açabilir ve TMK m. 26/2 gereği adı haksız olarak kullanılan kişi bu haksız kullanıma son verilmesini; haksız kullanan kusurlu ise ayrıca maddi zararının giderilmesini ve uğradığı haksızlığın niteliği gerektiriyorsa manevi tazminat ödenmesini isteyebilir.

Yukarıda ifade edilen davalar, TMK m. 25 hükmünde düzenlenen kişiliği koruyan davalardan pek farklı değildir. Gerçekten de TMK m. 25 hükmüne göre, hak sahibi hakimden saldırı tehlikesinin önlenmesini, sürmekte olan saldırıya son verilmesini, sona ermiş olsa bile etkileri devam eden saldırının hukuka aykırılığının tespitini talep edebilir. Yine hak sahibi düzeltmenin veya kararın üçüncü kişilere bildirilmesi ya da yayımlanması isteminde de bulunabilir ve son olarak hakkı saldırıya uğramış taraf maddi ve manevi tazminat istemleri ile hukuka aykırı saldırı dolayısıyla elde edilmiş olan kazancın vekaletsiz iş görme hükümlerine göre kendisine verilmesine ilişkin istemde bulunabilir. Görüldüğü üzere TMK m. 25 ve 26 hükümleri birbirine çok yakın koruyucu davaları düzenlemektedir. Nitekim yukarıda açıklandığı üzere TMK m. 26 hükmü, m. 25 hükmünün ad bakımından düzenlenen özel bir hükmü niteliğindedir.

Belirtmek gerekir ki TMK m. 26 hükmü adın haksız kullanılması veya ada ilişkin bir çekişmenin ortadan kaldırılmasına ilişkin uyuşmazlıkları ele alırken, ada yönelik saldırılar aynı zamanda başka bir kişilik hakkını ihlal ediyorsa; örneğin adın kişilik haklarından olan şeref ve haysiyete aykırı kullanımı TMK m. 25 hükmü kapsamında korunacaktır ${ }^{5}$.

\section{Koruyucu Davalar}

TMK m. 26 hükmünde adın korunmasına ilişkin olarak yapılan ilk düzenleme ada karşı yönelmiş, mevcut veya devam eden saldırılara karşı hak sahibine bunların önlenmesi, tespiti ve durdurulmasına ilişkin dava açma hakkı şeklinde birtakım imkânlar tanınmıştır. Bu doğrultuda bahsedeceğimiz davaları genel manada koruyucu davalar olarak adlandırmakla beraber bu davalar TMK m. 26 hükmünde yer aldığı üzere, saldırının tespiti davası, saldırıya son verme davası ve son olarak saldırının önlenmesi davası olarak karşımıza çıkar.

58 Akkurt, s. 49. 


\section{a. Saldırının Tespiti Davası}

Adın kullanılmasının çekişmeye meydan vermesi ve kişinin bir adı taşıyamayacağı yönündeki itirazlar neticesinde kişinin, çekişmeye konu olan adı taşımaya ilişkin hakkı olduğuna dair tespit davası açma hakkı TMK m. 26 hükmünde açıç̧a düzenlenmiştir. Gerçekten de TMK m. 26/1'e göre adının kullanılması çekişmeli olan kişi, bu hakkının tespiti için dava açabilir. Buna göre, kişinin kullandığı ada ilişkin herhangi bir çekişmenin olduğu durumlarda, kişi ada ilişkin hakkının tespitini mahkemeden talep edebilir. Adın kullanımına ilişkin çekişme, kişinin adını kullanmaya hakkı olmadığı itirazı ile ortaya çıkar59. Öyle ki kişinin bu adı kullanamayacağı yönündeki itiraz, adın bir başkasının adıyla karışması sebebiyle o şahsın şahsi menfaatlerinin zarar görmesi ihtimalinin varlığı halinde meydana gelir ${ }^{60}$. Bu durumda kişi saldırının tespiti davasını açarak, bunun devamında adın kullanımının durdurulmasını sağlayabilir.

Adın kullanımının çekişme oluşturması hali, sosyal medya mecralarında da ortaya çıkar. Sosyal medya mecralarında genellikle aynı kullanıcı adlarını edinmek zordur. Hatta sosyal medya ortamlarında, uygun kullanıcı adını, daha doğru bir ifadeyle kullanılmamış bir kullanıcı adını tespit edebilme hizmetini sağlayan web siteleri de mevcuttur ${ }^{61}$. Bilindiği üzere birçok sosyal medya mecrasında kullanıcılar aynı adları elde edememekte ve bunun yerine kişiler aynı kullanıcı adlarını, belirgin özellikleri kaybolmayacak şekilde onlara birkaç yazı karakteri veya rakam ekleyerek edinmektedir. Örneğin sosyal medya mecralarında bir futbolcunun, siyasetçinin, sanatçının veya sosyal medya fenomeninin, kullanıcı adlarına veya öz adlarına benzer binlerce kullanıcı adı görmek mümkündür. Bu isimler sosyal medya mecralarında teknik olarak aynen edinilemese de bu adların başına, ortasına veya sonuna birkaç rakam ve/veya yazı karakteri eklenerek adın haksız olarak kullanımı ortaya çıkmaktadır. Belirtmek gerekir ki haksız şekilde kullanılan bu sosyal medya adlarının TMK m. 26'da düzenlenen korumadan yararlanabilmesi mümkün değildir. Çünkü bu korumadan yararlanabilmek bakımından bu adı kullanan kişinin korunmaya değer haklı bir menfaatinin bulunması gerekir. Bu menfaatin bulunduğundan bahsedebilmek için ise, saldırının tespitine konu olacak adın kişiyi ayırt edici ve tanımlayıcı özelliğinin var olması gerekir.

Sosyal medya ortamında belirli bir isimde tanınmış bir kullanıcıya karşı,

59 Oğuzman, Seliçi, Oktay-Özdemir, s. 136.

60 Özdemir, s. 584.

61 bkz. https://namechk.com, https://www.namecheckr.com, https://checkusernames.com, https://www.spinxo.com/username-check vb. 
üçüncü kişiler bu adı kullanmakta hakkı olmadığı yönünde itirazlarda bulunulabilir $^{62}$. Bu halde aleyhine adın kullanılmasına karşı itirazda bulunulan taraf, mahkemeye başvurarak hakimden kendisine, o adı kullanmaya hakkı oluğunun tespit edilebilmesini talep edebilecektir. Ancak, adın kullanılmasının çekişme meydana getirebilmesi bakımından, bu kullanımın süreklilik arz etmesi ve yanlışlıkla yapılmamış olması gerekmektedir ${ }^{63}$. Fakat kanaatimizce tek sefere mahsus adın kullanılması çekişmeye mahal vermese de şartlar oluştuğunda adı haksız kullanan taraftan tazminat talep edilebilecektir.

Bunun yanında, davanın kim tarafından açıldı̆̆ı davanın müspet veya menfi tespit davası olup olmadığını belirleyecektir. Buna göre çekişmeli adın kendi lehine tespitini talep eden tarafın açtığı dava müspet tespit, üçüncü kişi tarafından açılan dava ise menfi tespit davası olacaktır ${ }^{64}$.

\section{b. Saldırıdan Men Davası (Saldırının Durdurulması)}

Bir kimsenin sahip olduğu ada karşı yönelmiş bir saldırı olması, daha doğru bir ifade ile kişinin sahip olduğu adın bir başkası tarafından haksız bir biçimde kullanılması ${ }^{65}$ mümkündür. Örneğin bir kişinin adının bir başkası tarafından kullanılması, adın bir cismi, eşyayı ve/veya hayvanı tanımlamak için kullanılması adın haksız kullanımı teşkil eder ${ }^{66}$. Bu durumu engellemek amacıyla kanun koyucu TMK m. 26/2 hükmünde, ada karşı gerçekleşen saldırının durdurulması, ortadan kaldırılmasına ilişkin ad sahibinin, haksız saldırıda bulunan tarafa karşı saldırıdan men davası açabilmesi imkânını düzenlemiştir. Buna göre adı haksız olarak kullanılan kişi bu haksız kullanıma son verilmesini mahkemeden talep edebilir ${ }^{67}$.

Sosyal medya mecralarında bu davanın konusunu oluşturabilecek meselelerle karşılaşılabilir. Gerçekten de nüfusa veya sicile kayıtlı olup olmamasına bakılmaksızın TMK m. 26 kapsamında korunma kapsamına giren birçok adın sosyal medya mecralarında saldırıya uğraması söz konusu olabilir. Zira sosyal medya mecralarında herhangi bir tanınmış sosyal medya adının yanına herhangi bir harf, rakam veya yazı karakteri eklenerek kullanılması mümkündür. Bu durum, saldırıya uğrayan ad sahipleri bakımından TMK m. 26/2 hükmüne dayanarak saldırıdan men davası açılmasına sebebiyet verebilir. Bu hüküm sayesinde adın

62 TMK m. 26/1 hükmüne dayanarak açılacak davada, davalı tarafın, davacının adına itiraz ederek çekişmeyi meydana getiren kişi olduğuna ilişkin olarak bkz. Oğuzman, Seliçi, Oktay-Özdemir, s. 136.

63 Özdemir, s. 584.

64 Öztan, s. 299.

65 Adın haksız kullanılmasından bahsetmek için adın kısmen değil tamamının kullanılması gerekir. bu yöndeki görüşler için bkz. Dural, Öğüz, s. 176

66 Özsunay, s. 204; Özdemir, s. 585; Dural, Öğüz, s. 176.

67 Yarg. 4. HD., 2015/4457 E., 2016/3497 K., 17.03.2016 T., Akkurt, s. 49, dipnot: 114'ten naklen. 
sahibi, adını haksız olarak kullanan kişinin bu kullanımına engel olabilir.

Belirtmek gerekir ki TMK m. 26/2 hükmünde, saldırıdan men davasının açllabilmesi için adın haksız kullanımı sonucu bir zararın meydana gelmesi şartı ve bu haksız kullanımda bulunan tarafın kusurlu olup olmaması önem taşımamaktadır. Her ne kadar doktrinde, saldırıdan men davası açılabilmesi bakımından, bu saldırının bir zarar doğurması gerektiğinden bahsedilmiş olsa $\mathrm{da}^{68}$, madde gerekçesinde açıkça belirtildiği üzere saldırıya son vermek isteyen tarafın zarara uğraması veya karşı tarafın kusurunun olup olmaması bu dava bakımından bir şart değildir ${ }^{69}$. Nitekim madde gerekçesi, "maddenin sadece "adın gasba karşı korunmasın”", yani adın başkaları tarafindan haksız olarak kullanılmasını düzenlediği göz önünde tutularak, "buna son verilme davasını" zarar ve kusur koşulların gerektirmediği...” şeklindedir.

Belirtmek gerekir ki, ad sahibinin TMK m. 26/2 kapsamında bir saldırıdan men davası açabilmesi için, mevcut saldırının haksız olması gerekir. Nitekim saldırının haksız olmaması, ad sahibinin adının korunmasında korumaya değer bir menfaatinin bulunmadığı manasına gelecektir. Çünkü sosyal medya ortamında birden çok benzer isim kullanılması mümkündür. Bu sebeple öz adı veya soyadı birbirine benzer kişilerin bu adı haksız kullandığından bahisle ada karşı saldırının durdurulması iddiasında bulunulamayacaktır.

\section{c. Saldırının Önlenmesi Davası (Önleme Davası)}

TMK m. 26 hükmünde açıkça belirtilmemesine rağmen, ada karşı haksız bir saldırının gerçekleşeceği, daha açıkça belirtmek gerekirse adın haksız olarak kullanılacağı yönünde bazı belirtilerin olması durumunda, adın sahibinin saldırının önlenmesi davası yoluyla adının korunmasını isteme hakkı mevcuttur ${ }^{70}$.

$\mathrm{Bu}$ davanın konusunu oluşturacak saldırı tehlikesi sosyal medya ortamında da oluşabilecektir. Bu durumda adının haksız olarak kullanılacağına ilişkin bilgileri edinen kişi adına karşı gerçekleşecek saldırının önlenmesi için dava açabilecektir.

68 Akipek, Akıntürk, Ateş, s. 435.

69 Yarg. 11. HD., 2018/2197 E., 2019/3702 K., 13.5.2019 T., (28.11.2019), www.kazanci.com: “... orijinal sahne isminin (evlilik öncesi gerçek isim ve soyisminin) ondan izinsiz olarak ayak giysilerinde ticari tanıtım vasıtası olarak kullanıldığının anlaşılmış olmasına göre, davacının bu uğurda uğradiğı bir zararın varhı̆̆ şartı aranmaksızın yukarıdaki ilkeler doğrultusunda davalıdan maddi tazminat talep edebileceğinin kabulü gerekirken, hatah gerekçeyle, isim hakkmin ihlali yönünden maddi tazminat isteminin reddine karar verilmesi doğru görülmediğinden Bölge Adliye Mahkemesi kararmın bu gerekçeyle da temyiz eden davacı yararina bozulması gerekmiştir."

70 Ataay, s. 195; Öztan, s. 299; Akipek, Akıntürk, Ateş, s. 436; Özsunay, s. 207; Oğuzman, Seliçi, Oktay-Özdemir, s. 137. 
Yine bu dava bakımından gerçekleşmesi muhtemel saldırının haksız olması aranmaktadır. Nitekim saldırı henüz gerçekleşmediğinden saldırıda bulunma ihtimali olan tarafın kusurlu olmasına veya ada karşı yapılacak saldırıya ilişkin bir zarar şartının aranmasına bu dava bakımından da gerek olmadığı kanaatindeyiz.

\section{Zararların Giderilmesini Sağlayan Davalar}

Ada karşı yönelmiş saldırılar sonucunda, adı haksız olarak kullanılan taraf uğramış olduğu zararları, zarara sebebiyet veren taraftan talep edebilecektir. Nitekim ada yönelmiş haksız saldırılar sonucu açılabilecek davalar TMK m. 26/2 hükmünde düzenlenmiştir. Buna göre adı haksız olarak kullanan kusurlu ise adın sahibi ayrıca maddi zararının giderilmesini ve uğradığı haksızlığın niteliği gerektiriyorsa manevi tazminat ödenmesini talep edebilecektir ${ }^{71}$.

\section{a. Maddi Tazminat Davası}

Bilindiği üzere Türk hukuk sisteminde, maddi tazminatın talep edilebilmesi için aranan ilk şart zararın doğmasıdır. Bu halde ada yönelik gerçekleşen haksız saldırıya karşı maddi tazminat talep edilebilmesi açısından, ada yönelik saldırıları bertaraf eden davalardan farklı olarak zarar şartı aranacaktır. Gerçekten de adın haksız olarak kullanılması adın sahibi bakımından zarar şartı gerçekleştiğinde, bu haksız saldırının doğurduğu zararlar bakımından saldırıda bulunan taraftan maddi tazminat talep edilebilecektir.

Bununla birlikte, adına karşı gerçekleşen saldırılara ilişkin maddi tazminat talep eden taraf, karşı tarafın bu haksız kullanımı gerçekleştirmesinde kusurlu olduğunu ispat etmelidir ${ }^{72}$. Zira TMK m. 26/2 hükmü de adı haksız kullananın kusurlu olmasını maddi zararının talep edilebilmesi için bir şart olarak öngörmüştür. Belirtmek gerekir ki, kusuru olmaksızın zarara sebebiyet veren tarafın tazmin yükümlülüğü olmayacaktır.

\section{b. Manevi Tazminat Davası}

Adın haksız olarak kullanılması sonucu zarara uğrayan tarafın maddi tazminat talep edebileceğini yukarıda belirtmiş olmakla beraber, manevi bir zarara uğrayan kişinin de bu zararı sebebiyle adı haksız olarak kullanan tarafa manevi

71 Yarg. 11. HD., 2018/2197 E., 2019/3702 K., 13.5.2019 T., (28.11.2019), www.kazanci.com: “4021 Sayılı TMK’nın 25 vd. maddeleri uyarınca, bir kişinin ismi üzerinde vazgeçilemez ve devredilemez nitelikte temel kişilik hakları ile bu hakka yönelik saldırları def etme ve isminin haksız olarak kullanılması nedeniyle de uğradığı zararların tazminini talep etme haklarl bulunmaktadrr."

72 Oğuzman, Seliçi, Oktay-Özdemir, s. 137. 
tazminat davası açabilmesi TMK m. 26/2 hükmünde düzenlenmiştir.

Gerçekten de TMK m. 26/2 hükmünde adı haksız kullanılan kişi uğradığ haksızlı̆̆ın niteliği gerektiriyorsa manevi tazminat ödenmesini adı haksız kullanan taraftan isteyebilecektir. Ancak kanunda yer alan "uğradığı haksızhğın niteliği gerektiriyorsa” ifadesi bu hükmün TBK m. 58 hükmü ile beraber uygulanıp uygulanamayacağına ilişkin tartışmalar doğurmuştur73. Bir görüşe göre madde metninde yer alan "uğradığı haksızh̆̆ın niteliği gerektiriyorsa manevi tazminat ödenmesini” ifadesi sebebiyle hakim haksızlığın niteliğini değerlendirerek manevi tazminat yerine TBK m. 58/2 hükmü gereği başka bir giderim biçimi kararlaştırabilir veya bu giderim biçimini tazminata ekleyebilir; özellikle saldırıyı kınayan bir karar verebilir ve bu kararın yayımlanmasına hükmedebilir74. Ancak bu hususta kanun gerekçesi açıktır. Buna göre, adın haksız kullanılması sebebiyle manevi zarara uğrayan taraf hakimden yalnızca manevi tazminat talep edebilecektir. Nitekim bu hükme ilişkin kanun gerekçesi şu şekildedir: "Maddenin bu fikrasında manevî tazminat istemi, İsviçre Medenî Kanununun 29 uncu maddesine uygun olarak sadece bir miktar paranın verilmesine yönelik olmaktadır. Bu niteliği vurgulamak üzere "manevî tazminat ödenmesini” ifadesine yer verilmiştir."

\section{Sonuç}

Ad, bireylerin toplum içinde tanınmasını sağlayan, onu diğer kişilerden ayırma işlevine sahip, kişilik hakkı niteliğinde olan bir kelimedir. TMK kapsamında ad ile birlikte kişiyi ayırt etmeye yarayan tüm işaretler korunur. Ad, kişilik hakkı teşkil ettiğinden kişiye sıkı sıkıya bağlı bir hak olup miras yoluyla geçmez, temlik edilemez ve bu hakkın uzun süre kullanılmaması, adın kaybına yol açmaz.

Gerçek ve tüzel kişilerin toplumda diğer bireylerden kendilerini ayırmak, kendilerini tanıtmak için onları bireyselleştirmeye yarayan araçlara ihtiyacı vardır. Bu ihtiyaç tüm kişiler bakımından ad ile karşılanabilecektir. Ancak bunun yanında soyadından da bahsetmek gerekir. Tüzel kişiler bakımından soyadından bahsedilemeyecek olsa da gerçek kişiler açısından bu adın da kişilerin ayırt edilmesinde ve tanınmasında kullanılan bir araç olduğundan bahsedebilecektir. Tüzel kişiler bakımından ise ayırt etme ve tanıtma fonksiyonu adın yanında ticari unvan, işletme adı gibi araçlar ile de sağlanabilecektir.

Adın türleri bakımından dar ve geniş anlamda ad şeklinde bir ayrım yapmak gerekir. Dar anlamda ad olarak tanımlanan ad, hukuk düzenince tanınan kişi-

73 Akipek, Akıntürk, Ateş, s. 436.

74 Akipek, Akıntürk, Ateş, s. 436. 
lerin sahip olduğu gerçek addır. Bu tanımlama kapsamında adın iki unsurdan oluştuğunu belirtmek gerekir. Bunlar kişinin sahip olduğu öz ad ve soyadıdır. Bununla birlikte geniş anlamda ad, kişileri tanıtmaya yarayan ve hukuken korunan kelime ve sembollerin tümünü ifade eder. Geniş anlamda ad kavramı, kişinin toplum ve diğer bireylerden kendini ayırdığı, kendini tanıtmaya yarayan araçlardandır. Bu sebeple geniş anlamda ad kavramı kapsamına girebilecek adları sayı ile sınırlamak mümkün değildir.

Geniş anlamda adın kapsamını sayıyla sınırlamak mümkün olmamakla beraber, kişiyi diğer bireylerden ayırt eden ve onu tanıtan bu araçlardan bazılarını ortaya koymak gerekir. Bunlardan ilki, bir kişinin gerçek adını kullanmak yerine çeşitli sebeplerle kendisine takmış olduğu addır. Bu ada müstear ad denir. Gerçekten müstear adda, öz ad ve soyadı gibi kişiyi tanımlar, bireyselleştirir ve diğer kişilerden ayırma fonksiyonunu tesis eder. Bu tür adları genellikle sanatçılar, yazarlar ve çeşitli sanat faaliyetlerinde gerçek adlarını gizlemek için kullanırlar. Bunun yanında geniş ad kapsamına giren bir başka adda lakaptır. Nitekim lakap bir kişiye başkaları tarafından bir ayırt edici özelliği kullanılarak takılan addır. Bu ad başkaları tarafından kişinin belirgin özelliklerine göre belirli bir çevrede takılır ve kişi bu lakabı sayesinde anılır, ayırt edilir. Dolayısıyla kişinin toplum içerisinde bireyselleşme fonksiyonu bu ad türünde de sağlanır. Ancak bu adların TMK m. 26 kapsamında korunup korunamayacağını ele almak gerekir. Nitekim doktrinde mahlas ve lakapların korunabilmesi için kişinin bu adlar ile tanınmış olması ve dolayısıyla kişinin bu hakkının korunmasını sağlayacak menfaatlerinin bulunması gerektiği ifade edilmiştir.

Kişilerin fiziki ortamlarda olduğu gibi, sosyal mecralarda da kendilerini diğer üyelerden veya kullanıcılardan ayırdıkları en önemli bireyselleştirme ve tanıtma aracı adlarıdır. Bu doğrultuda sosyal medya kullanıcılarının çeşitli sosyal mecralarda edindiği adların TMK m. 26 kapsamında korunabilmesi açısından kişilerin bu mecralar üzerinde elde ettiği isimlerin sınıflandırılması gerekmektedir. Nitekim bu sınıflandırma sonucunda, hangi sosyal medya isimlerinin TMK kapsamında korunabileceği ortaya çıkacaktır. Biz de eserimizde sosyal medya adları bakımından üçlü bir ayrıma giderek şu şekilde bir tasnifte bulunduk: (1) Nüfusa veya sicile kayıtlı sosyal medya adları, (2) nüfusa veya sicile kayıtlı olmayan sosyal medya adları ve (3) anonim sosyal medya adları.

Kendi sistemlerinde faaliyette bulunabilmeleri için üye olma şartı arayan ve dolayısıyla kişilerin kullanıcı adı almasının zorunlu olduğu sosyal mecralarda, kişiler nüfusa veya sicile kayıtlı isimlerini kullanabilecektir. Dolayısıyla bu kişiler, sosyal medya mecralarından edindikleri kullanıcı adlarıyla, bu mecralarda kendilerini bireyselleştirme, tanıtma ve diğer kullanıcılardan ayırt 
edilebilme fonksiyonunu bu kullanıcı adları ile sağlayabilecektir. Hatta bazı sosyal medya mecralarında kişilerin, hesaplarının çeşitli yollarla doğrulanması sağlanarak, kişilere o sosyal medya bakımından tek yetkili hesap (resmi hesap) statüsü sağlanmaktadır. Bu adların korunabilmesi bakımından, kişilerin ayrıca korunmaya değer bir menfaatinin olup olmadığına bakılmayacaktır. Çünkü bu kişiler korumayı sosyal medya üzerinde olsa da gerçek adları bakımından yapacaktır.

Buna karşın sosyal medya mecralarında nüfusa kayıtlı olmayan adları kullanan birçok kullanıcı mevcuttur. Bu adların kişilere bireyselleştirme ve onları tanıtma fonksiyonuna sahip olduğunun kabul edilmesi gerekmektedir. Hatta son yıllarda sosyal medyanın hızla gelişmesi sebebiyle kişilerin kendilerini tanıtma ve onların toplum içerisinde bireyselleştirilme fonksiyonunu en çok sağladığı aracın sosyal medya olduğu kabul edilebilir. Ancak bu adların, adın korunması kapsamında yer alıp almayacağı tartışma konusudur. Bir görüşe göre bu adlar TMK m. 26 kapsamında yer almayıp, eğer şartları sağlıyorsa kişilik hakkı kapsamında koruncaktır. Ancak bizim de katıldığımız diğer bir görüşe göre, müstear ad ve lakap bakımından aranan, adın korunması için korunmaya değer bir menfaatin bulunması şartı bu adlar bakımından da geçerli olacak ve bu adların bu menfaati onu kullanana sağlaması halinde, bu adda adın korunması hükümlerinden yararlanabilecektir.

Nüfusa kayıtlı olmayan isimlerin sosyal medya mecralarında kullanılmasının bir diğer hali de anonim adlarda ortaya çıkacaktır. Gerçekten de bazı sosyal medya mecralarının kullanımı için kişilerin üyeliği ve dolayısıyla bu mecralarda kullanıcı adının alınması gerekmez. Bununla beraber bazı sosyal medya mecralarında ise kişiler her zaman aynı anonim ada sahip olurlar. Bu durumda kişileri tanıtma ve onları diğer üyelerden ayırma fonksiyonunu bu anonim adlar vasıtası ile sağlayabilmek mümkün olabilecektir. Bu halde aynı menfaat şartının gerçekleştiği durumlarda TMK m. 26 kapsamında bu adlar da korunabilecektir. Fakat anonim olarak sosyal medya mecralarında hareket eden kullanıcıların genellikle, o mecralardaki kullanıcı, misafir isimleri, sisteme her girişlerinde değiştiğinden, bu kişiler bakımından TMK kapsamında gerçek bir ad kullandıklarından bahsedilemeyecektir. Çünkü anonim kişilerin sosyal medya mecralarında kullandıkları adlar, adın bireyselleşme ve diğer kullanıcılardan ayırt edilme fonksiyonunu sağlamamaktadır. Bu halde bu adların TMK m. 26 kapsamında korunmasından bahsedilemeyecektir.

Adın korunmasına ilişkin olarak TMK m. 26 hükmü hak sahibine çeşitli davaları açabilme hakkı tanımıştır. Buna göre adının kullanılması çekişmeli olan kişi, TMK m. 26/1 gereği bu hakkının tespiti için dava açabilir ve TMK m. 26/2 gereği adı haksız olarak kullanılan kişi bu haksız kullanıma son verilmesini; 
haksız kullanan kusurlu ise ayrıca maddi zararının giderilmesini ve uğradığı haksızlığın niteliği gerektiriyorsa manevi tazminat ödenmesini isteyebilecektir. Belirtmek gerekir ki TMK m. 26 hükmü adın haksız kullanılması veya ada ilişkin bir çekişmenin ortadan kaldırılmasına ilişkin uyuşmazlıkları ele alırken, ada yönelik saldırılar aynı zamanda başka bir kişilik hakkını ihlal ediyorsa, koruma TMK ve TBK'nın kişilik hakkı koruması kapsamına giren diğer hükümleri ile de sağlanabilecektir. 


\section{KAYNAKLAR}

- Aka, Beyza, "Sosyal Medyada Kişilik İhlalleri ve Hukuki Korunma Yolları", İzmir Barosu Dergisi, Sayı: 2, Mayıs 2017, s. 231- 287.

- Akipek, Jale; Akıntürk, Turgut; Ateş, Derya, Türk Medeni Hukuku Başlangıç Hükümleri Kişiler Hukuku, Cilt 1, 14. Bası, Beta Yayıncılık, İstanbul, 2018.

- Akkurt, Sinan Sami, Sosyal Medyada Gerçekleşen İhlaller Karşısında Kişilik Hakkının Korunması, Seçkin Yayıncılık, Ankara, 2019.

- Andreas M. Kaplan; Michael Haenlein, "Users of the World, Unite! The Challenges and Opportunities of Social Media", Business Horizons, Sayı 53, 2010, s. 59-68,

- Ataay, Aytekin, Şahıslar Hukuku: Giriş, Hakikî Şahıslar, Cilt 1, 2. Bası, İstanbul Üniversitesi Yayınları, İstanbul, 1969.

- Ayan, Mehmet; Ayan, Nurşen, Kişiler Hukuku, 8. Bası, Seçkin Yayıncılık, Ankara, 2016.

- Brunty, Joshua; Helenek, Katherine, Social Media Investigations for Law Enforcement, Anderson Publishing, Massachusetts, 2013.

- Boyd, Danah M.; Ellison, Nicole B., "Social Network Sites: Definition, History and Scholarship", Journal of Computer-Mediated Communication, Sayı 13, 2008, s. 210230.

- Dural, Mustafa, Türk Medeni Hukukunda Gerçek Kişiler, Filiz Kitabevi, İstanbul, 1995 .

• Dural, Mustafa; Öğüz, Tufan, Türk Özel Hukuku Kişiler Hukuku, Cilt 2, 14. Bası, Filiz Kitabevi, İstanbul, 2014.

- Eda, Sarp, “İsim Hakkı ve İsmin Korunması", Bursa Barosu Dergisi, Cilt: 37, Sayı: 93, 2013, s. 59-75.

• Gönen, Doruk, Tüzel Kişilerde Kişilik Hakkı ve Korunması, On İki Levha Yayıncılık, İstanbul, 2011.

- Hatemi, Hüseyin, Kişiler Hukuku, 7. Bası, On İki Levha, İstanbul, 2018.

• Hayrunnisa Özdemir, "Türk ve İsviçre Medenî Hukukunda Ad Üzerindeki Hak ve Korunması", Ankara Üniversitesi Hukuk Fakültesi Dergisi, Cilt: 57, Sayı: 3, 2008, s. 561-598.

- Helvacı, Serap, Gerçek Kişiler, Legal Yayıncılık, İstanbul, 2017.

- Helvacı, Serap, Türk ve İsviçre Hukuklarında Kişilik Hakkın Koruyucu Davalar, Beta Basım Yayın, İstanbul, 2001.

• Kaya, Mine, "Sosyal Medya ve Sosyal Medyada Üçüncü Kişilerin Kişilik Haklarının İhlali”, Türkiye Barolar Birliği Dergisi, Sayı 119, 2015, s. 277- 306.

- Kaya, Mine, “Telekomünikasyon Alanında Kişilik Haklarının Korunması”, Ankara Barosu Dergisi, Cilt 68, Sayı 4, 2010, s. 279- 339.

- Oğuzman, Kemal; Seliçi, Özer; Oktay-Özdemir, Saibe, Kişiler Hukuku, 17. Bası, Filiz Kitabevi, İstanbul, 2018. 
214 Sosyal Medya Adları ve Türk Medeni Kanunu m. 26 Kapsamında Sosyal Medya Adlarının Korunması

- Özsunay, Ergun, Gerçek Kişilerin Hukuki Durumu, 4. Bası, İstanbul Üniversitesi Yayınları, İstanbul, 1979.

- Öztan, Bilge, Medeni Hukukun Temel Kavramlar, 36. Bası, Turhan Kitabevi, Ankara, 2012.

- www.checkusernames.com

- www.kazanci.com

- www.namecheckr.com

- www.namechk.com

- www.jurix.com.tr

- www.spinxo.com/username-check 